\title{
The Evaluation of Groundwater Resources Value of Beijing Based on Emergy Theory
}

\author{
Ling Wang ${ }^{1,2}$ and Qing $\mathrm{He}^{1,2}$ \\ ${ }^{1}$ School of Humanities and Economic Management, China University of Geosciences, Beijing 100083, China \\ ${ }^{2}$ Key Laboratory of Carrying Capacity Assessment for Resource and Environment, Ministry of Land and Resources, \\ Beijing 100083, China \\ Correspondence should be addressed to Ling Wang; wang006699@163.com
}

Received 11 August 2014; Revised 15 October 2014; Accepted 24 October 2014

Academic Editor: Hanlie Hong

Copyright (C) 2015 L. Wang and Q. He. This is an open access article distributed under the Creative Commons Attribution License, which permits unrestricted use, distribution, and reproduction in any medium, provided the original work is properly cited.

\begin{abstract}
Accurate yet valid evaluation of values of groundwater resources is difficult. However, it is of an urgent need. Based on water resource system, the emergy synthesis of the ecological economics was used to make a systematic study on the assessment of the quantity of groundwater resources. Taking Beijing in 2012 as an example, the values of groundwater for residents life subsystem, the industrial subsystem, and the agricultural subsystem are 7.64, 6.00, and 3.25 billion Yuan, accounting for 45.24, 35.5, and 19.24\% of the total value, respectively. The total value of the underground water accounts for $1.51 \%$ of the GDP in Beijing for that year. Meanwhile, Contribution Rate of Groundwater Resources (GWCR) in Beijing decreased in the following order: groundwater contribution rate for industry (GWCRI 4.52\%), groundwater contribution rate for agriculture (GWCRA 3.24\%), and groundwater contribution rate for residential life (GWCRL 0.71\%). The conclusions will provide important basis for the government's scientific decision to improve the level of comprehensive management of water resource.
\end{abstract}

\section{Introduction}

As a part of the natural resources, the groundwater provides valuable water for most people to support agricultural and industrial production activities. About two-thirds of people in China use groundwater as their drinking water, and about two-thirds of cities and farmlands take groundwater as their main water supply, especially in Northern China, where the development is heavily dependent on the exploitation of groundwater [1]. The evaluation of groundwater resources is a practical problem to be solved in social development. It is important to use the groundwater reasonably and to realize the coordinated development between economic society and environment.

The evaluation of groundwater resource value is a scientific issue remaining to be solved. At present, the methods widely accepted to value the water resources are (1) system model method, such as the fuzzy mathematic model [2-5], CGE model [6], and shadow price model [7-12]; (2) market analysis method, such as the supply and demand pricing model [13] and the marginal opportunity cost model [14-17]; and (3) nonmarket method, such as the contingent valuation method [18].

The above-mentioned methods all attempt to monetize water resources and human economy activities, to use the currency as the only way to measure wealthy, but currency cannot measure everything, particularly the essence of nature and laws. Water (groundwater) is a kind of natural resource and its value cannot be measured by money totally because the currency in circulation does not pass through natural world. Currency is only a tool to measure human's role and contribution in economic activities, not the role and contribution of economy and nature. Groundwater provides the vast majority of people with valuable water resource and sustains agriculture and industry. At the same time, the pollution of water mainly arises from human's activities [19]. Therefore, research on groundwater resource value can be made from its contribution to industrial production, agricultural production, and residential life.

The new method of groundwater evaluation is the emergy theory of ecological economics. Emergy theory is reviewed as the value theory of environment and natural resources. 


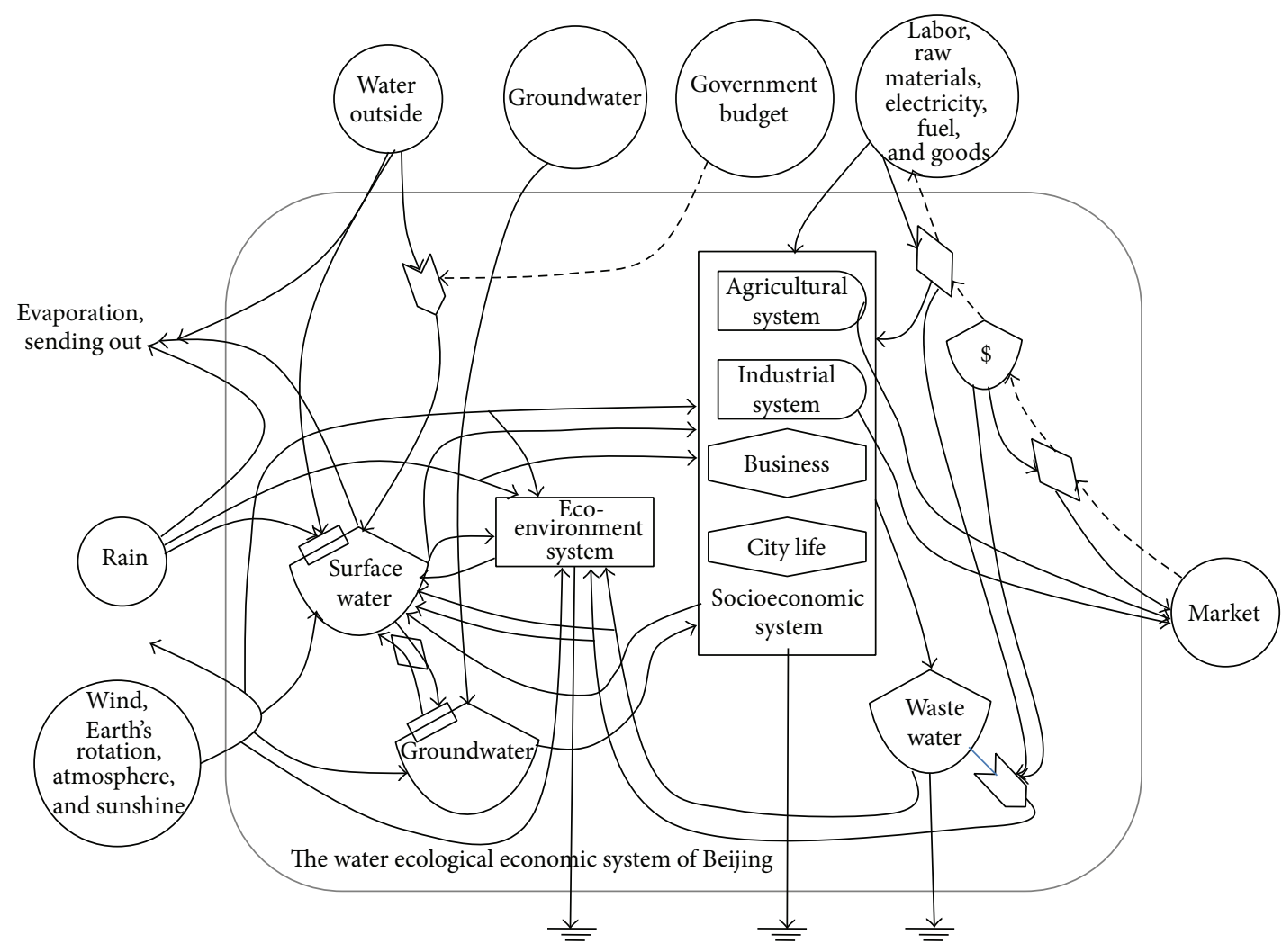

FIGURE 1: Diagram of eco-economic inputs and outputs within and outside the RWEES (regional water ecological-economic system).

The essence of the emergy theory is translating different forms of energy and materials into solar energy. In 2000, the emergy theory was applied to the field of water resources by Buenfil for the first time. Buenfil simulated and optimized the allocation of water in city, agriculture, and environment of Florida, America. In 2001, Buenfil calculated the emergy transform rates of the main rivers, aquifers, and eight water plants in Florida. Xie [20] analyzed the water environment value of Tumen River Basin using the emergy theory. Chen [21] applied the emergy method to the evaluation of natural water resources and regarded coastal county in southern China as an example for practical application. Lv [22] conducted a systematic study of emergy evaluation of ecological economic value of water resources.

Based on the energy recycling and transformation in water eco-economic system and the construction principles of energy and emergy network, the energy and emergy network of water eco-economic system and its subsystems are constructed in this paper, including industrial subsystem, agricultural subsystem, and residential subsystem. In the light of the current situation of economy development and water exploitation in Beijing, the groundwater resource value was checked from 2008 to 2012, which will provide theoretical basis and techniques for the proper decision and evaluation of water exploitation.

\section{Theory and Method}

Emergy, specifically solar emergy, is the available solar energy used up directly and indirectly to make a service of product
[23]. Therefore we can measure the emergy of all kinds of energy based upon the solar energy. The solar emergy owned by any sources, products, or services is the amount of solar energy they used directly or indirectly for their formation, and its unit is solar emjoules (sej).

\subsection{The Energy Network of Water Resource System and Its Subsystem}

(1) The Energy and Emergy Network of Water Eco-Economic System. According to the basic structure of water resources eco-economic system and the main condition of ecologicaleconomic flow including energy sources, material, and information, the energy network of water resources ecologicaleconomic system is constructed (Figure 1). The basic structure of regional water ecological-economic system, the relationship of ecological and economic flow and its main direction, water circulation flow path, and the relationship between economic-social production and ecological environment will be clear. And then emergy/dollar ratio (EDR) is calculated as follows:

$$
\begin{aligned}
\operatorname{EDR}(\text { sej } / ¥) & =\frac{\mathrm{EM}_{U}}{\text { GDP Comparision Price }} \\
& =\frac{\mathrm{EM}_{R}+\mathrm{EM}_{N}+\mathrm{EM}_{F}-\mathrm{EM}_{\mathrm{EX}}}{\text { GDP Coparision Price }},
\end{aligned}
$$


where $\mathrm{EM}_{U}$ is total emergy used; $\mathrm{EM}_{R}$ is renewable emergy; $\mathrm{EM}_{N}$ is nonrenewable emergy; $\mathrm{EM}_{F}$ is feedback emergy; and $\mathrm{EM}_{\mathrm{EX}}$ is export emergy.

(2) The Energy and Emergy Network of Industrial, Agricultural, and Residential Subsystem. According to the directions of main energy flow, material flow, and monetary flow of industrial, agricultural, and residential subsystem, each subsystem's energy and emergy network can be constructed and the emergy flow of each subsystem will be calculated. Three more indices emphasizing the contribution rate of groundwater resources (GWCR) were developed:

$$
\begin{aligned}
\mathrm{GWCR}_{I} & =\frac{\text { Emergy of Groundwater within Industry }}{\text { All Emergy Input within Industry }}, \\
\mathrm{GWCR}_{A} & =\frac{\text { Emergy of Groundwater within Agriculture }}{\text { All Emergy Input within Agriculture }},
\end{aligned}
$$

$$
\mathrm{GWCR}_{L}=\frac{\text { Emergy of Groundwater within Residents life }}{\text { All Emergy Input within Residents life }} .
$$

\subsection{Transformity of Different Water Bodies with the Method} of Emergy Calculation. The biggest challenge of the emergy analysis is the calculation of transformity ( $\mathrm{Tr}$ ) of all sorts of energy, material, information, and service. So far, lots of significant achievements of the international emergy research have been accomplished. Odum and other researchers over the world (such as Brown et al. [24]) calculated the transformity of the emergy of the main energies and substances. With this transformity of the emergy we can do some generic systematic emergy analysis that could be conducted. It is necessary to calculate more detailed transformity of the emergy between resources and substances according to professional systems. For example, for the ecologically economical systems of the water resources, just the rainwater emergy transformity is not enough; calculating more detailed classifications of the water solar emergy transformity is required. The UEV (unit of emergy value) of a system can be considered as an efficiency indicator. For example, Brown et al. [24] stated that "UEVs are inversely related to the system efficiency on the scale of the biosphere." In other terms, a more efficient overall use of resources by the coupled humannatural system has a lower UEV. The UEVs of the natural water, the engineering water, and the recycled water were calculated, respectively, as follows:

\section{UEV of Natural water}

$$
\begin{aligned}
& =\frac{\text { Total Emergy of the watershed rainfall }(\mathrm{sej} / \mathrm{a})}{\text { Mass of The catchment water capacity per year }\left(\mathrm{m}^{3} / \mathrm{a}\right)} \\
& =(\text { Rainfall per year } \times \text { Gibbs energy of rain } \\
& \quad \times \text { Tr of the Rain })
\end{aligned}
$$

$$
\begin{gathered}
\times(\text { Mass of Total water per year } \\
\div \text { Refresh Cycle Time })^{-1}
\end{gathered}
$$

UEV of Engineering water

$=($ Total Emergy of Engineering water

$$
\text { Input per year }(\mathrm{sej} / \mathrm{a}))
$$

$$
\times\left(\text { Mass of Total water per year }\left(\mathrm{m}^{3} / \mathrm{a}\right)\right)^{-1} \text {, }
$$

UEV of Recycled Water

$$
\begin{aligned}
& =(\text { Total Emergy input within Waste } \\
& \quad \text { water treatment per year }(\operatorname{sej} / \mathrm{a})) \\
& \times\left(\text { Mass of Total Recycled water per year }\left(\mathrm{m}^{3} / \mathrm{a}\right)\right)^{-1} .
\end{aligned}
$$

\section{Case Study}

3.1. Study Area. Beijing, the capital of China, located in the northwest of the North China Plain, is a municipality directly under the control of the central government and also the political and economic center. Its geographic coordinates for longitude and latitude are $115^{\circ} 25^{\prime}-117^{\circ} 30^{\prime} \mathrm{E}$ and $39^{\circ} 28^{\prime}-41^{\circ} 05^{\prime} \mathrm{N}$, with a total area of $16410.54 \mathrm{~km}^{2}$. In 2012 , the GDP of Beijing is 1787.94 billion yuan, with a population of 20.693 million. The population density is 1251 capita $/ \mathrm{km}^{2}$. And per-capita water supply is $173 \mathrm{~m}^{3}$, which is lower than the world average (Figure 2). Groundwater resource is not only a basic resource for the development of Beijing, but also strategic resources and the important guarantee for Beijing's development. With groundwater accounting for $1 / 2$ of the city's water supply, Beijing is one of the few big cities that regard groundwater as the main source of water supply. With the rapid development of the urban construction and the process of rural urbanization, an increase of the urban population, the conflict between supply and demand of water in the city is more serious. The excessive exploitation of groundwater has caused a series of environmental problems, such as land subsidence and ground fissure, and shortage of groundwater has become a bottleneck of the economic and sustainable development of Beijing.

\subsection{Results and Discussion}

(1) Calculation of EDR in Beijing Based on the Regional System Emergy Analysis. According to a comprehensive analysis of the main energy flow, material flow, and monetary flow inside and outside of Beijing water resources ecological-economic system, the emergy index datum, including renewable resources emergy $\left(\mathrm{EM}_{R}\right)$, nonrenewable resources emergy $\left(\mathrm{EM}_{N}\right)$, feedback input emergy $\left(\mathrm{EM}_{F}\right)$, and the system emergy export $\left(\mathrm{EM}_{\mathrm{EX}}\right)$, the total emergy used $\left(\mathrm{EM}_{U}\right)$ of 
TABLE 1: The Summary of the main emergy indexes about the water system of Beijing (unit: $10^{20}$ sej).

\begin{tabular}{|c|c|c|c|c|c|}
\hline Emergy indexes & 2008 & 2009 & 2010 & 2011 & 2012 \\
\hline $\mathrm{EM}_{R}$ & 459 & 324.2 & 378.12 & 397.98 & 508.66 \\
\hline $\mathrm{EM}_{N}$ & 1202.36 & 1287 & 1318.71 & 1107.09 & 976.8 \\
\hline Renewable environmental resources products & 712.77 & 727.47 & 711.05 & 698.29 & 687.95 \\
\hline $\mathrm{EM}_{F}$ & 8138.62 & 8618.9 & 11371.8 & 14863.4 & 17508.9 \\
\hline $\mathrm{EM}_{\mathrm{EX}}$ & 3918.5 & 3998.3 & 5528.98 & 7296.26 & 8367.11 \\
\hline $\mathrm{EM}_{U}$ & 5881.48 & 6231.8 & 7539.61 & 9072.26 & 10627.2 \\
\hline $\mathrm{EM}_{Y}$ & 75465.1 & 83250 & 89993.4 & 96928.6 & 96935.7 \\
\hline Annual water emergy consumption $\mathrm{EM}_{W}$ & 333.65 & 364.63 & 383.55 & 351.5 & 385.67 \\
\hline Water from external $\mathrm{EM}_{\mathrm{WE}}$ & 1.83 & 6.12 & 6.72 & 8.03 & 9.58 \\
\hline Water from local $\mathrm{EM}_{\mathrm{WL}}$ & 284.06 & 310.52 & 324.03 & 303.37 & 332.97 \\
\hline Emergy/\$ EDR $\left(10^{11} \mathrm{sej} / \$\right)$ & 46.29 & 44.31 & 48.51 & 51.35 & 59.84 \\
\hline Emergy/RMB EDR (10 $10^{11}$ sej/¥) & 6.76 & 6.49 & 7.26 & 8.11 & 9.51 \\
\hline
\end{tabular}

The data of Table 1 have been summarized. The regional data reference is from the following books: $[25,26]$.

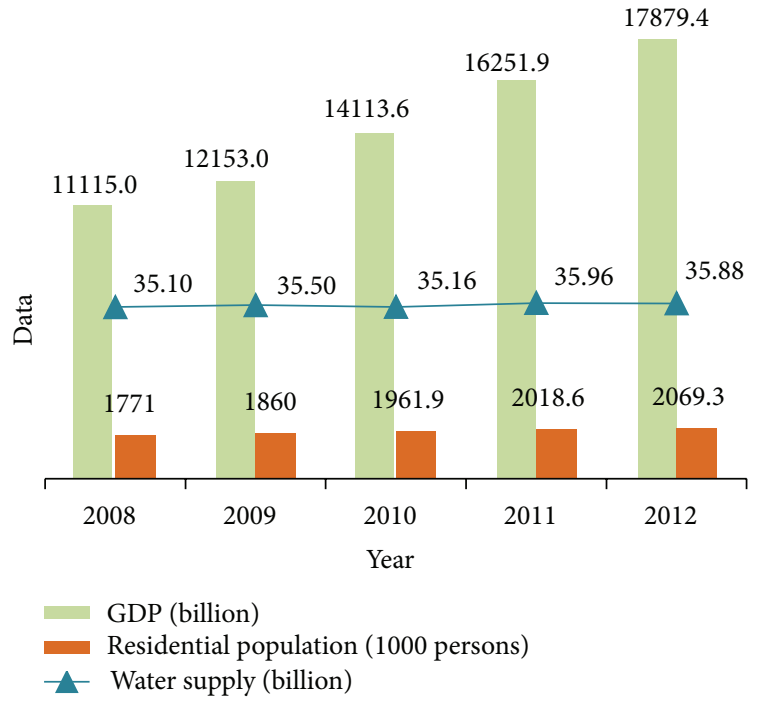

FIGURE 2: The population of permanent residents, water supply, and gross domestic product (GDP) of Beijing. Source: [25].

the system emergy yield $\left(\mathrm{EM}_{Y}\right)$, and annual water emergy $\left(\mathrm{EM}_{W}\right)$, was calculated. The complex emergy network chart of the regional water ecological-economic system (RWEES) in Beijing was constructed (Figure 3).

After arranging the raw data, analysis of energy, material, and monetary flows in Beijing, the emergy flow of all kinds of resources, material, and monetary in the system was classified and established. EDR (emergy/RMB) was calculated (Table 1).

(2) Calculation of Transformity of Different Water Bodies in Beijing. The natural water in Beijing can be generally divided into two kinds: surface water and groundwater. Based on the method of the calculation of transformity of different water bodies, transformity of surface water, groundwater, and engineering water from 2008 to 2012 in Beijing was counted (Table 2).
In accordance with the scale of the water supply of the 9th Water Plant which takes the surface water as source water and the 8th Water Plant which takes groundwater as the source water in Beijing, based on the Standards of Urban Water Supply Construction Project, the input and output amounts of emergy of the water plant were reckoned. The emergy transformity of different water bodies in Beijing was calculated as shown in Table 3 with formulas (5), (6), and (7) above and the original data reference from the following references: [30-35].

(3) Emergy Analysis of Groundwater Resources Value regarding the Industrial Subsystem as an Example. According to the main directions of energy flow, material flows in the industrial subsystem, and the relations of production in the system in Beijing, the industrial subsystem emergy network was established (Figure 4). 


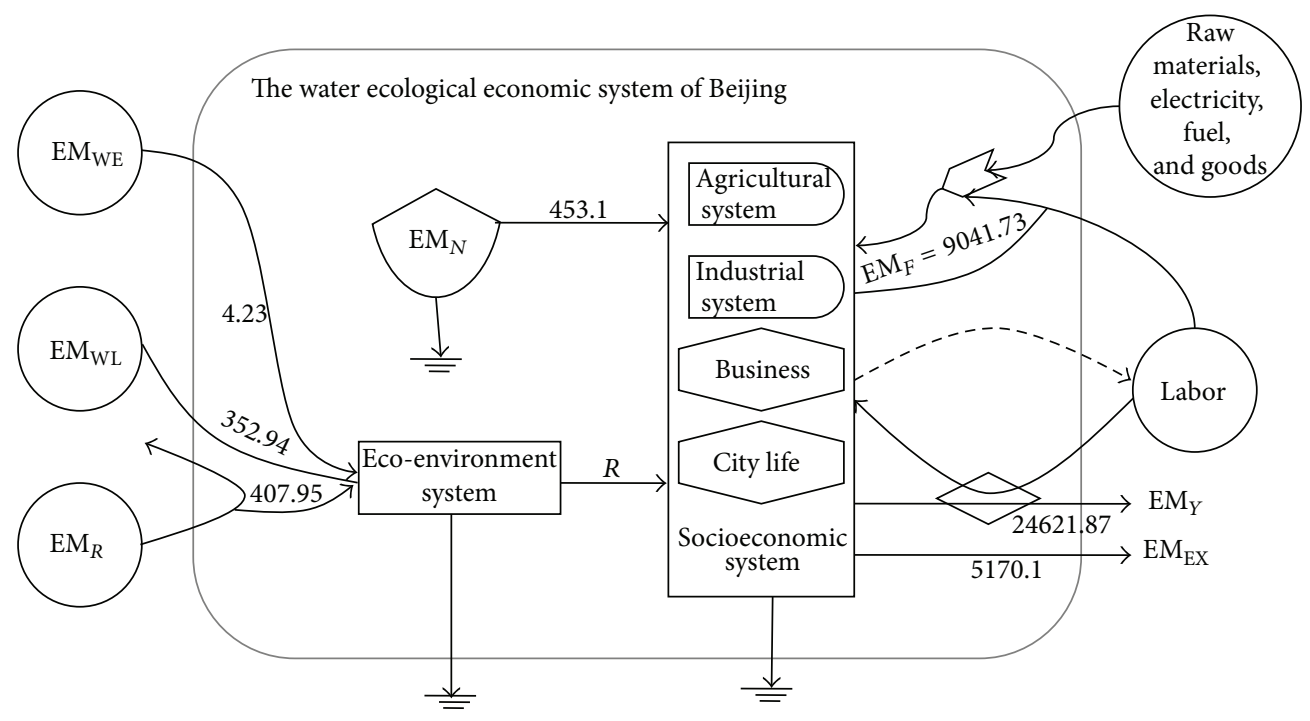

Figure 3: Aggregated figure of emergy flows for RWEES (units: emergy $10^{20} \mathrm{sej}$ ).

TABLE 2: Transformity of the engineering water of Beijing, 2008-2012.

\begin{tabular}{|c|c|c|c|c|c|}
\hline Item & 2008 & 2009 & 2010 & 2011 & 2012 \\
\hline Raw surface water $\left(10^{11} \mathrm{sej} / \mathrm{m}^{3}\right)$ & 4.27 & 7.77 & 7.37 & 5.6 & 5.09 \\
\hline Raw groundwater $\left(10^{11} \mathrm{sej} / \mathrm{m}^{3}\right)$ & 24 & 28.39 & 29.04 & 28.93 & 29.04 \\
\hline $\begin{array}{l}\text { The raw south-to-north diversion project water } \\
\text { (Raw SNDP water) }\left(10^{11} \mathrm{sej} / \mathrm{m}^{3}\right)\end{array}$ & 1.99 & 1.99 & 1.99 & 1.99 & 1.99 \\
\hline Water diversion costs $\left(¥ / \mathrm{m}^{3}\right)$ & 0.39 & 0.39 & 0.39 & 0.39 & 0.39 \\
\hline Reservoir construction costs $\left(¥ / \mathrm{m}^{3}\right)$ & 1.53 & 1.53 & 1.53 & 1.53 & 1.53 \\
\hline Tube and wells pumping station construction costs $\left(¥ / \mathrm{m}^{3}\right)$ & 0.32 & 0.32 & 0.32 & 0.32 & 0.32 \\
\hline The south-to-north diversion project water investment $\left(¥ / \mathrm{m}^{3}\right)$ & 3.35 & 3.35 & 3.35 & 3.35 & 3.35 \\
\hline EM\$ $\left(10^{11}\right.$ sej/¥) & 6.76 & 6.49 & 7.26 & 8.11 & 9.51 \\
\hline Engineering surface water $\left(10^{11} \mathrm{sej} / \mathrm{m}^{3}\right)$ & 17.21 & 20.2 & 21.28 & 21.14 & 23.3 \\
\hline Engineering surface water $\left(10^{11} \mathrm{sej} / \mathrm{m}^{3}\right)$ & 28.77 & 32.97 & 34.17 & 34.66 & 35 \\
\hline Engineering SNDP water $\left(10^{11} \mathrm{sej} / \mathrm{m}^{3}\right)$ & 24.61 & 23.71 & 26.3 & 29.15 & 33.8 \\
\hline
\end{tabular}

Original source: Beijing Water Statistical Yearbook [26-29].

TABLE 3: Engineering water, tap water, and recycled water emergy per volume.

\begin{tabular}{lccc}
\hline Item & Tap water & & Recycled water \\
& From surface water & From groundwater & 1.19E+13 \\
\hline Emergy per volume $\left(\mathrm{sej} / \mathrm{m}^{3}\right)$ & $3.13 E+13$ & $3.25 E+13$ & \\
\hline
\end{tabular}

Through the collection, classification, and collation of the original data of energy, material, and money flows of Beijing industrial subsystem, the emergy flow of the industrial subsystem from 2008 to 2012 was obtained. Taking 2012 as an example, the calculation result was shown in Table 4.

Among them, the solar energy and the wind energy are obtained from all the Beijing area. Nonrenewable resources are calculated on the basis of the data of standard coal given in the Beijing Statistical Yearbook. The raw materials, labor, operation expenses, and fixed assets are expressed in currencies.

With formula (2) and summarizing the data in Table 4 (the data of 2008-2011 can't be shown in this paper, for the limited space), the emergy of groundwater for industry and GWCR $_{I}$ of Beijing from 2008 to 2012 was shown in Table 5. For the better comparison of different years, the amount of money involved in the process of calculation is based on the comparable prices calculated of 2008 . 
TABLE 4: Emergy inputs and outputs within and outside BIS (Beijing industrial system), 2012.

\begin{tabular}{|c|c|c|c|c|c|}
\hline & Item & Raw data & Unit & Transformity (sej/unit) & Emergy $\left(10^{20}\right.$ sej $)$ \\
\hline 1 & Total inputs & & & & 3592.76 \\
\hline 1.1 & Renewable environmental resources & & & & 67.43 \\
\hline 1.1.1 & Solar & $7.19 E+19$ & $\mathrm{~J}$ & $1^{*}$ & 0.72 \\
\hline 1.1.2 & Wind & $1.38 E+17$ & $\mathrm{~J}$ & $632^{*}$ & 0.87 \\
\hline 1.1 .3 & Industrial water & $48.9 E+07$ & $\mathrm{~m}^{3}$ & & 65.84 \\
\hline 1.1.3.1 & Tap water & $12.05 E+07$ & $\mathrm{~m}^{3}$ & & 40.40 \\
\hline 1.1.3.1.1 & From surface water & $6.17 E+07$ & $\mathrm{~m}^{3}$ & $3.29 E+13$ & 20.34 \\
\hline 1.1.3.1.2 & From groundwater & $5.87 E+07$ & $\mathrm{~m}^{3}$ & $3.41 E+13$ & 20.06 \\
\hline 1.1 .3 .2 & Engineering water from surface water & $5.77 E+07$ & $\mathrm{~m}^{3}$ & $0.23 E+13$ & 1.34 \\
\hline 1.1.3.3 & Engineering water from groundwater & $15.4 E+07$ & $\mathrm{~m}^{3}$ & $0.35 E+13$ & 5.40 \\
\hline 1.1.3.4 & Recycled water & $15.7 E+07$ & $\mathrm{~m}^{3}$ & $1.19 E+13$ & 18.70 \\
\hline 1.2 & Nonrenewable environmental resources & & & & 3525.33 \\
\hline 1.2 .1 & Energy & $6.67 E+17$ & $\mathrm{~J}$ & $39800^{*}$ & 265.44 \\
\hline 1.2 .2 & Raw material, labor, and other fees & $26.75 E+10$ & $¥$ & $9.51 E+11^{*}$ & 2543.08 \\
\hline 1.2 .3 & ${ }^{*}$ Fixed assets depreciation & $7.54 E+10$ & $¥$ & $9.51 E+11^{*}$ & 716.81 \\
\hline 2 & Total outputs & & & & 8051.12 \\
\hline 2.1 & Farm and sideline food & $3.5 E+10$ & $¥$ & $9.51 E+11^{*}$ & 332.33 \\
\hline 2.2 & Textile and garment industry & $1.92 E+10$ & $¥$ & $9.51 E+11^{*}$ & 182.44 \\
\hline 2.3 & Wood and furniture & $0.81 E+10$ & $¥$ & $9.51 E+11^{*}$ & 76.92 \\
\hline 2.4 & Chemical products & $3.46 E+10$ & $¥$ & $9.51 E+11^{*}$ & 328.76 \\
\hline 2.5 & Chemical & $5.43 E+10$ & $¥$ & $9.51 E+11^{*}$ & 516.44 \\
\hline 2.6 & Rubber and plastic & $1.1 E+10$ & $¥$ & $9.51 E+11^{*}$ & 104.57 \\
\hline 2.7 & Raw coal & $1.57 E+17$ & $\mathrm{~J}$ & $39800^{*}$ & 62.41 \\
\hline 2.8 & Crude oil & $4.41 E+17$ & $\mathrm{~J}$ & $66000^{*}$ & 291.11 \\
\hline 2.09 & Electricity & $10.47 E+17$ & $\mathrm{~J}$ & $1.59 E+05^{*}$ & 1664.66 \\
\hline 2.10 & Steel & 26000 & $\mathrm{t}$ & $1.78 E+15^{*}$ & 0.46 \\
\hline 2.11 & Glass & $2.54 E+06$ & $\mathrm{t}$ & $8.4 E+13^{*}$ & 2.13 \\
\hline 2.12 & Cement & $8.75 E+06$ & $\mathrm{t}$ & $1.98 E+15^{*}$ & 173.15 \\
\hline 2.13 & General equipment industry outputs & $5.25 E+10$ & $¥$ & $9.51 E+11^{*}$ & 498.77 \\
\hline 2.14 & Special equipment industry outputs & $5.1 E+10$ & $¥$ & $9.51 E+11^{*}$ & 485.07 \\
\hline 2.15 & Transportation equipment manufacturing industry & $27.22 E+10$ & $¥$ & $9.51 E+11^{*}$ & 2586.97 \\
\hline 2.16 & Electrical machinery and equipment manufacturing & $6.70 E+10$ & $¥$ & $9.51 E+11^{*}$ & 636.54 \\
\hline \multirow[t]{3}{*}{2.17} & Other manufacturing & $0.56 E+10$ & $¥$ & $9.51 E+11^{*}$ & 53.46 \\
\hline & Industrial waste water & $1.46 E+15$ & $\mathrm{~J}$ & $3.76 E+06^{*}$ & 54.92 \\
\hline & Contribution rate of groundwater resources $\%$ & & & & 1.83 \\
\hline
\end{tabular}

Original source: $[25,26]$.

Transformity of Table 4 marked with “*” sited from Lv [22] and Odum [23]. Other Tr without “*” are calculated with the original data.

Similarly, the emergy value of the groundwater for agricultural and living subsystems can be obtained. The summary of groundwater resources value in Beijing was shown in Table 6.

According to the results, the groundwater emergy value and monetary value of the industrial subsystem both show a steady trend from 2008 to 2012. Monetary value per volume of groundwater for industry was slightly decreased in the later 2 years because of the promotion of water-saving awareness and the implementation water saving action.
The groundwater emergy value and monetary value of the agricultural subsystem in Beijing kept a stationary fluctuation trend. Compared to a year earlier, the emergy value of the agricultural subsystem in the last three years rose slightly. This is due to the effect of agricultural irrigation and water saving policies; in addition, an increase in efficiency of farming is another reason.

In addition, a rising trend in these years of groundwater resources value can be seen in general, although there were slight fluctuations in the middle years. For example, monetary 


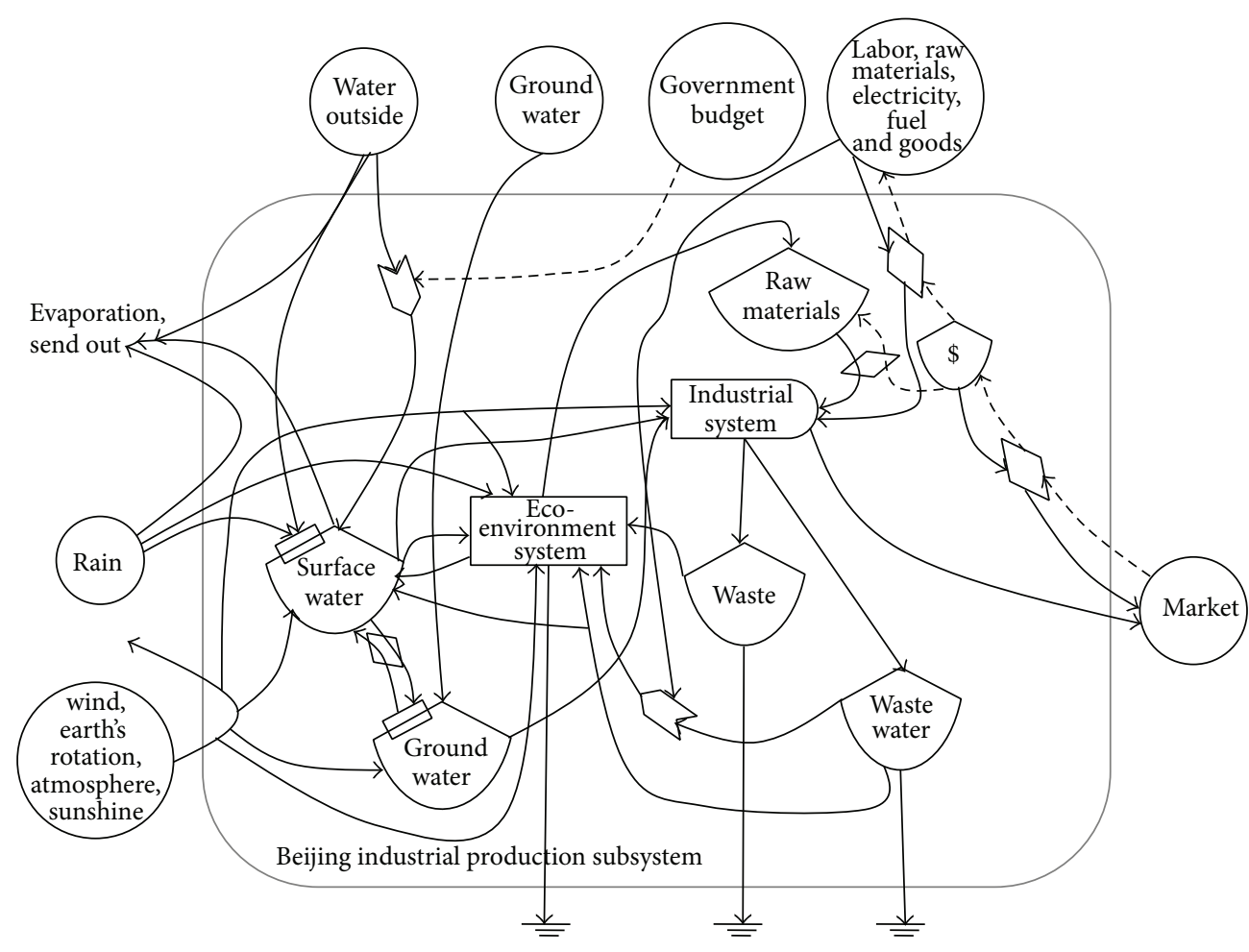

FIGURE 4: Figure of energy flows for Beijing industrial subsystem network.

TABLE 5: The water resource contribution rate and value of Beijing industry system (2008-2012) (unit: $10^{20}$ sej).

\begin{tabular}{|c|c|c|c|c|c|}
\hline Item & 2008 & 2009 & 2010 & 2011 & 2012 \\
\hline Emergy of water for industry & 56.30 & 60.74 & 59.51 & 63.05 & 65.84 \\
\hline Emergy of groundwater for industry & 24.97 & 25.24 & 23.17 & 23.69 & 25.45 \\
\hline Total emergy inputs for industry & 1511.70 & 2938.67 & 3020.52 & 3254.55 & 3592.76 \\
\hline Total emergy outputs of industry & 3068.95 & 5164.62 & 6832.95 & 7050.51 & 5805.11 \\
\hline WCR for industry $(\%)$ & 3.73 & 2.07 & 1.97 & 1.93 & 1.83 \\
\hline GWCR for industry (\%) & 1.65 & 0.86 & 0.77 & 0.73 & 0.71 \\
\hline Emergy value of water resource for industry & 114.38 & 106.74 & 134.62 & 136.59 & 147.55 \\
\hline Emergy value of groundwater resource for industry & 50.70 & 44.36 & 52.43 & 51.33 & 57.04 \\
\hline EDR emergy/RMB (10 $10^{11}$ sej/¥) & 6.76 & 6.49 & 7.26 & 8.121 & 9.51 \\
\hline Monetary value of water resource for industry $\left(10^{9} ¥\right)$ & 16.92 & 16.45 & 18.53 & 16.83 & 15.52 \\
\hline Monetary value of groundwater resource for industry $\left(10^{9} ¥\right)$ & 7.50 & 6.83 & 7.22 & 6.33 & 6.00 \\
\hline Total volume of water resource for industry $\left(10^{8} \mathrm{~m}^{3}\right)$ & 5.2 & 5.23 & 5.06 & 5.01 & 4.89 \\
\hline Volume of water resource for industry $\left(10^{8} \mathrm{~m}^{3}\right)$ & 2.42 & 2.29 & 2.11 & 2.1 & 2.13 \\
\hline Emergy transformity of water used in industry $\left(10^{13} \mathrm{sej} / \mathrm{m}^{3}\right)$ & 22.0 & 20.4 & 26.6 & 27.3 & 30.2 \\
\hline Emergy transformity of groundwater used in industry $\left(10^{13} \mathrm{sej} / \mathrm{m}^{3}\right)$ & 2.09 & 1.94 & 2.48 & 2.45 & 2.68 \\
\hline The monetary value of water resource per volume for industry $\left(¥ / \mathrm{m}^{3}\right)$ & 32.55 & 31.45 & 36.63 & 33.60 & 31.74 \\
\hline The monetary value of groundwater resource per volume for industry $\left(¥ / \mathrm{m}^{3}\right)$ & 30.97 & 29.83 & 34.14 & 30.19 & 28.19 \\
\hline
\end{tabular}

value per volume of groundwater for residential life in 2008 is $14.22 ¥ / \mathrm{m}^{3}$, which is as much as $14.99 ¥ / \mathrm{m}^{3}$ in 2012 which is much lower than the average price of residents water $\left(5 ¥ / \mathrm{m}^{3}\right)$ in Beijing.

(4) The Summary of GWCR in Beijing. Comparing GWCR and $\mathrm{GWCR}_{A}$ in Beijing, for 5 years the average $\mathrm{GWCR}_{I}$ was
$0.944 \%$ and the average $\mathrm{GWCR}_{A}$ was $4.38 \%$ (Table 7 ). This is because agricultural production is generally dependent on the supply of water, but the degree of industrial production relying on water is low. In addition, urban water supply is mostly from reservoir water but rural wells water supply is mostly from groundwater in Beijing. 
TABLE 6: The summary table of Beijing groundwater value.

\begin{tabular}{|c|c|c|c|c|c|c|}
\hline Item & & 2008 & 2009 & 2010 & 2011 & 2012 \\
\hline \multirow{4}{*}{ Total emergy value $\left(10^{20}\right.$ sej $)$} & Groundwater for industry & 50.70 & 44.36 & 52.43 & 51.33 & 57.04 \\
\hline & Groundwater for agriculture & 30.81 & 27.45 & 30.48 & 33.43 & 30.89 \\
\hline & Groundwater for residential life & 44.2 & 43.9 & 52.1 & 57.2 & 72.6 \\
\hline & Total & 125.71 & 115.71 & 135.01 & 141.96 & 160.53 \\
\hline \multirow{4}{*}{ Total monetary value $\left(10^{9} ¥\right)$} & Groundwater for industry & 7.50 & 6.83 & 7.22 & 6.33 & 6.00 \\
\hline & Groundwater for agriculture & 4.56 & 4.23 & 4.20 & 4.12 & 3.25 \\
\hline & Groundwater for residential life & 6.54 & 6.77 & 7.17 & 7.05 & 7.64 \\
\hline & Total & 18.6 & 17.83 & 18.59 & 17.5 & 16.89 \\
\hline \multirow{3}{*}{ Monetary value per volume ( $\left.¥ / \mathrm{m}^{3}\right)$} & Groundwater for industry & 30.97 & 29.83 & 34.14 & 30.19 & 28.19 \\
\hline & Groundwater for agriculture & 5.02 & 4.82 & 5.10 & 5.19 & 4.44 \\
\hline & Groundwater for residential life & 14.22 & 14.19 & 14.88 & 14.61 & 14.99 \\
\hline
\end{tabular}

TABLE 7: The Summary table of contribution rate of water resources (unit: \%).

\begin{tabular}{|c|c|c|c|c|c|}
\hline Item & 2008 & 2009 & 2010 & 2011 & 2012 \\
\hline Contribution rate of water resources for industry (C-RWRI) & 3.73 & 2.07 & 1.97 & 1.93 & 1.83 \\
\hline Contribution rate of groundwater resources for industry (C-RGRI) & 1.65 & 0.86 & 0.77 & 0.73 & 0.71 \\
\hline Contribution rate of water resources for agriculture (C-RWRA) & 9.94 & 8.60 & 9.92 & 10.83 & 8.84 \\
\hline Contribution rate of groundwater resources for agriculture (C-RGRA) & 4.35 & 3.81 & 4.34 & 4.86 & 4.52 \\
\hline Contribution rate of water resources for residential life (C-RWRR) & 13.41 & 13.57 & 13.01 & 10.44 & 10.03 \\
\hline Contribution rate of groundwater resources for residential life (C-RWRR) & 4.42 & 4.10 & 3.91 & 3.38 & 3.24 \\
\hline
\end{tabular}

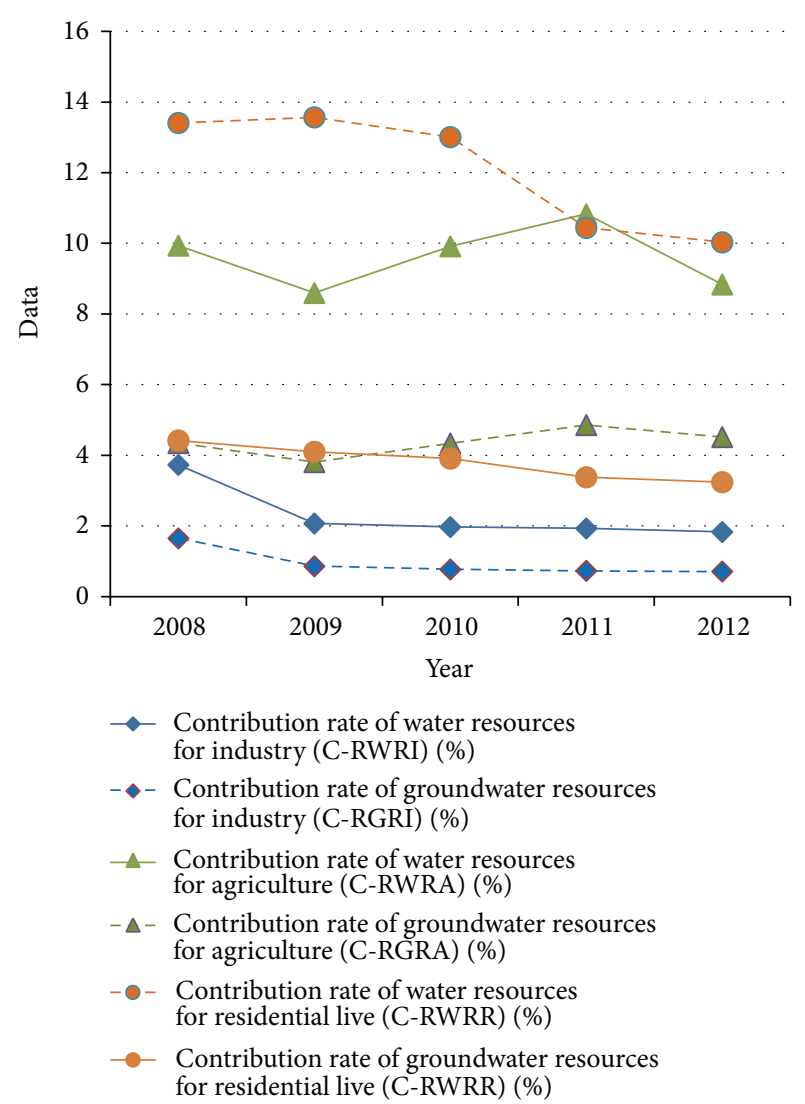

FIgURE 5: The summary table of contribution rate of water resources.
$\mathrm{GWCR}_{L}$ in Beijing showed a downward trend (Figure 5), falling from $4.42 \%$ in 2008 to $3.24 \%$ in 2012 . On the one hand, the residents' awareness of water saving is strengthened, and the South to North Water Diversion Project is gradually put into use.

\section{Conclusions}

Based on the principle of water cycle and the emergy theory of ecological economy, the frame of emergy evaluation of groundwater resources is constructed.

(1) The Evaluation of the Importance of Groundwater as a Basic Elements Involved in Each Subsystem. As a basic element for the residents' life, groundwater also supports the industry's production activities. Taking Beijing in 2012 as an example, in terms of monetary value of groundwater from big to small sorting, followed by groundwater for residents, for industrial, and for agricultural, its monetary value was 7.64, 6.00, and 3.25 billion yuan, accounting for $45.24 \%$, 35.52\%, and $19.24 \%$ of the total value, respectively. The total monetary value of the groundwater (16.89 billion yuan) accounts for $1.51 \%$ of the GDP (1118.059 billion yuan based on the comparable price of 2008) in Beijing.

(2) Predicting the GWCR of Each Subsystem. In 2012, the GWCR of each subsystem including $\mathrm{GWCR}_{A}, \mathrm{GWCR}_{L}$, and $\mathrm{GWCR}_{I}$ are $4.52 \%, 3.24 \%$, and $0.71 \%$, respectively. By further understanding the true value of groundwater and strengthening integrated management to water resources, the 
results can provide an important basis for scientific decisionmaking of the government.

\section{Conflict of Interests}

The authors declare that there is no conflict of interests regarding the publication of this paper.

\section{Acknowledgments}

The study is supported by the Social Science Foundation of China (13BJY063) and Beijing Planning Office of Philosophy and Social Science (12JGB065).

\section{References}

[1] F. Liu, "Brief review on achievements of groundwater contamination monitoring and remediation," Rock and Mineral Analysis, vol. 31, no. 4, pp. 645-646, 2012.

[2] Y. Hu and S. L. Cao, "On fuzzy comprehensive appraisal model for water resources worth," Journal of Shandong University (Engineering Science), vol. 33, no. 3, pp. 341-345, 2003.

[3] L. J. Wei, J. Q. Bao, and X. Y. Fu, "Application of the fuzzy mathematical model in evaluation of water resources value," Journal of Lanzhou Jiaotong University (Natural Sciences), vol. 25, no. 3, pp. 73-76, 2006.

[4] P. F. Lin, L. Q. Wang, and J. S. Zhang, "Modification and application of fuzzy mathematics model in evaluating loss of water resource value," Environmental Science and Technology, vol. 30, no. 1, pp. 66-68, 2007.

[5] C. Chen, Research on the value of quaternary groundwater based on GIS [Dissertation for doctoral degree], China University of Geosciences, Beijing, China, 2012.

[6] Y. Wang, "Study and simulation on water resources regulation in Zhangye City based on CGE model," Journal of Natural Resources, vol. 25, no. 6, pp. 959-966, 2010.

[7] C. M. Mao and R. H. Yuan, "Calculation and analysis of the theory value of water resources of Huanghe River," Resources and Environment, vol. 13, no. 3, pp. 25-29, 2003.

[8] I. A. Curtis, "Valuing ecosystem goods and services: a new approach using a surrogate market and the combination of a multiple criteria analysis and a Delphi panel to assign weights to the attributes," Ecological Economics, vol. 50, no. 3-4, pp. 163194, 2004.

[9] S.-K. Ning and N.-B. Chang, "Watershed-based point sources permitting strategy and dynamic permit-trading analysis," Journal of Environmental Management, vol. 84, no. 4, pp. 427-446, 2007.

[10] L. Diaz-Balteiro and C. Romero, "Valuation of environmental goods: a shadow value perspective," Ecological Economics, vol. 64, no. 3, pp. 517-520, 2008.

[11] W. Yang, J. Chang, B. Xu, C. Peng, and Y. Ge, "Ecosystem service value assessment for constructed wetlands: a case study in Hangzhou, China," Ecological Economics, vol. 68, no. 1-2, pp. 116-125, 2008.

[12] A. Tilmant, D. Pinte, and Q. Goor, "Assessing marginal water values in multipurpose multireservoir systems via stochastic programming," Water Resources Research, vol. 44, no. 12, 2008.

[13] H. Wang, Research of water resources value based on the theory of marginal utility [Dissertation for master degree], Beijing University of Technology, Beijing, China, 2012.
[14] J. T. Warlord, "Resources, environment and economic development. China population," Resources and Environment, vol. 1, pp. 78-83, 1992.

[15] M. L. Nieswiadomy, "Estimating urban residential water demand: effects of price structure, conservation, and education," Water Resources Research, vol. 28, no. 3, pp. 609-615, 1992.

[16] Z. H. Chen, "Positive analysis of water resource pricing B a sed on marginal opportunity cost," Journal of South-Central University for Nationalities (Natural Sciences), vol. 22, no. 3, pp. 75-77, 2003.

[17] M. H. Ali, M. R. Hoque, A. A. Hassan, and A. Khair, "Effects of deficit irrigation on yield, water productivity, and economic returns of wheat," Agricultural Water Management, vol. 92, no. 3, pp. 151-161, 2007.

[18] D. N. Barton, "The transferability of benefit transfer: contingent valuation of water quality improvements in Costa Rica," Ecological Economics, vol. 42, no. 1-2, pp. 147-164, 2002.

[19] F. Liu, S.-M. Wang, and H.-H. Chen, "Progress of investigation and evaluation on groundwater organic contaminants in western countries," Geological Bulletin of China, vol. 29, no. 6, pp. 907-917, 2010.

[20] Z. Y. Xie, "Research on water environment value of Tumen river basin in the way of emergy," Journal of Jilin Agricultural University, vol. 24, no. 3, pp. 68-72, 2002.

[21] D. Chen, J. Chen, and Z.-H. Luo, "Evaluation method of natural water resources based on energy theory and its application," Journal of Hydraulic Engineering, vol. 37, no. 10, pp. 1188-1192, 2006.

[22] M. C. Lv, Emergy evaluation of ecological economic value of regional water resources [M.S. thesis], Zhengzhou University, 2009.

[23] H. T. Odum, Environmental Accounting: Emergy and Environmental Decision Making, John Wiley \& Sons, New York, NY, USA, 1996.

[24] M. T. Brown and S. Ulgiati, "Energy quality, emergy, and transformity: H.T. Odum's contributions to quantifying and understanding systems," Ecological Modelling, vol. 178, no. 1-2, pp. 201-213, 2004.

[25] Beijing Statistical Yearbook, Beijing Water Statistical Yearbook, China Industrial Economy, Beijing Water Authority, 2008-2012.

[26] National Bureau of Statistics of the People's Republic of China, China Industrial Economy Statistics Yearbook, China Statistics Press, 2008-2012.

[27] J. C. Li, W. L. Jiang, and L. S. Jin, The Ecological Value Theory, Chongqing University Press, 1999.

[28] Q. K. Li, S. Y. Miao, and B. Z. Chen, "Well irrigation cost analysis of three areas in Hebei Province," Water Conservancy Planning and Analysis, vol. 4, pp. 41-45, 1994.

[29] H. Xu, Study on water price of multi-water resources in the reception basin of the south-north water transfer project: in Beijing as a case [Ph.D. thesis], China Institute of Water Resources and Hydropower Research, 2013 (Chinese).

[30] Beijing Water Statistical Yearbook (2008-2012), GB3838, 2014.

[31] Standards of the Surface Water Environment Quantity, GB8978, 2002.

[32] Integrated Wastewater Discharge Standard, ConstructionStandard, 1994/1574, 1996.

[33] Standards of Urban Water Supply Construction Project, Construction-Standard, 1994/1574, 1994.

[34] Standards of Urban Sewage Treatment, GB/T14848.93, 1994.

[35] Standards of the Groundwater Quantity, 1993. 

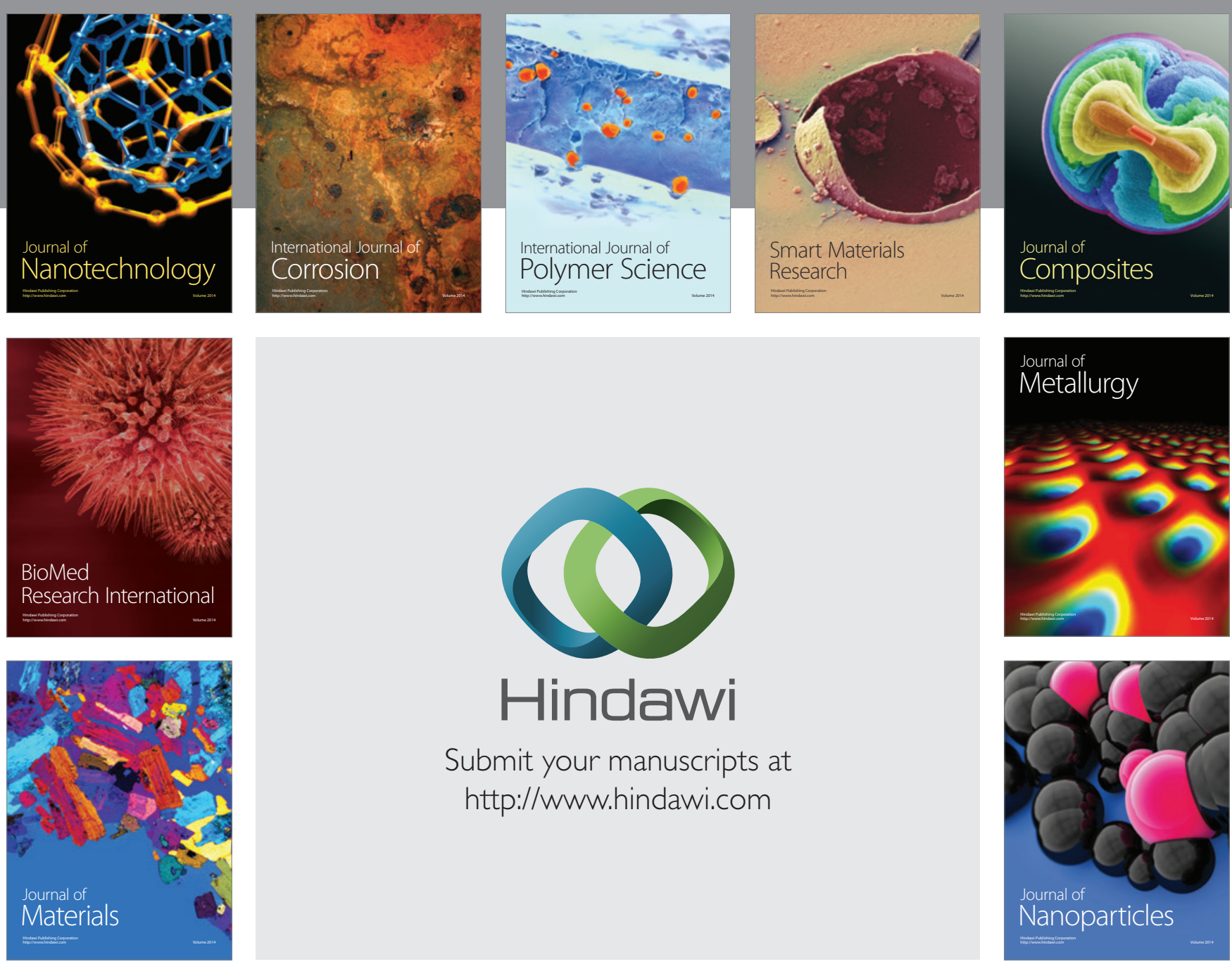

Submit your manuscripts at http://www.hindawi.com
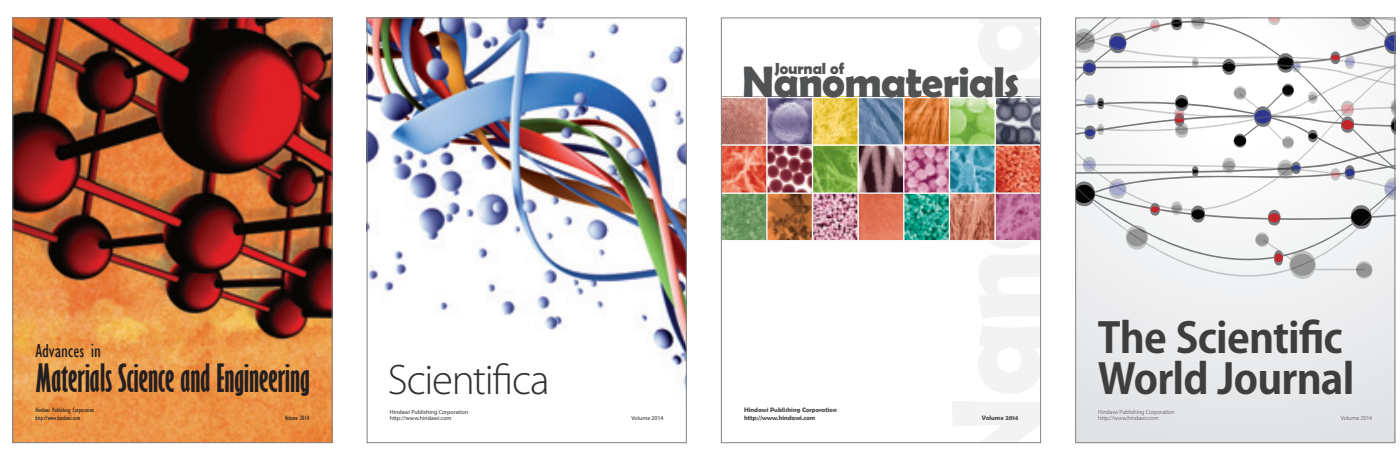

\section{The Scientific World Journal}
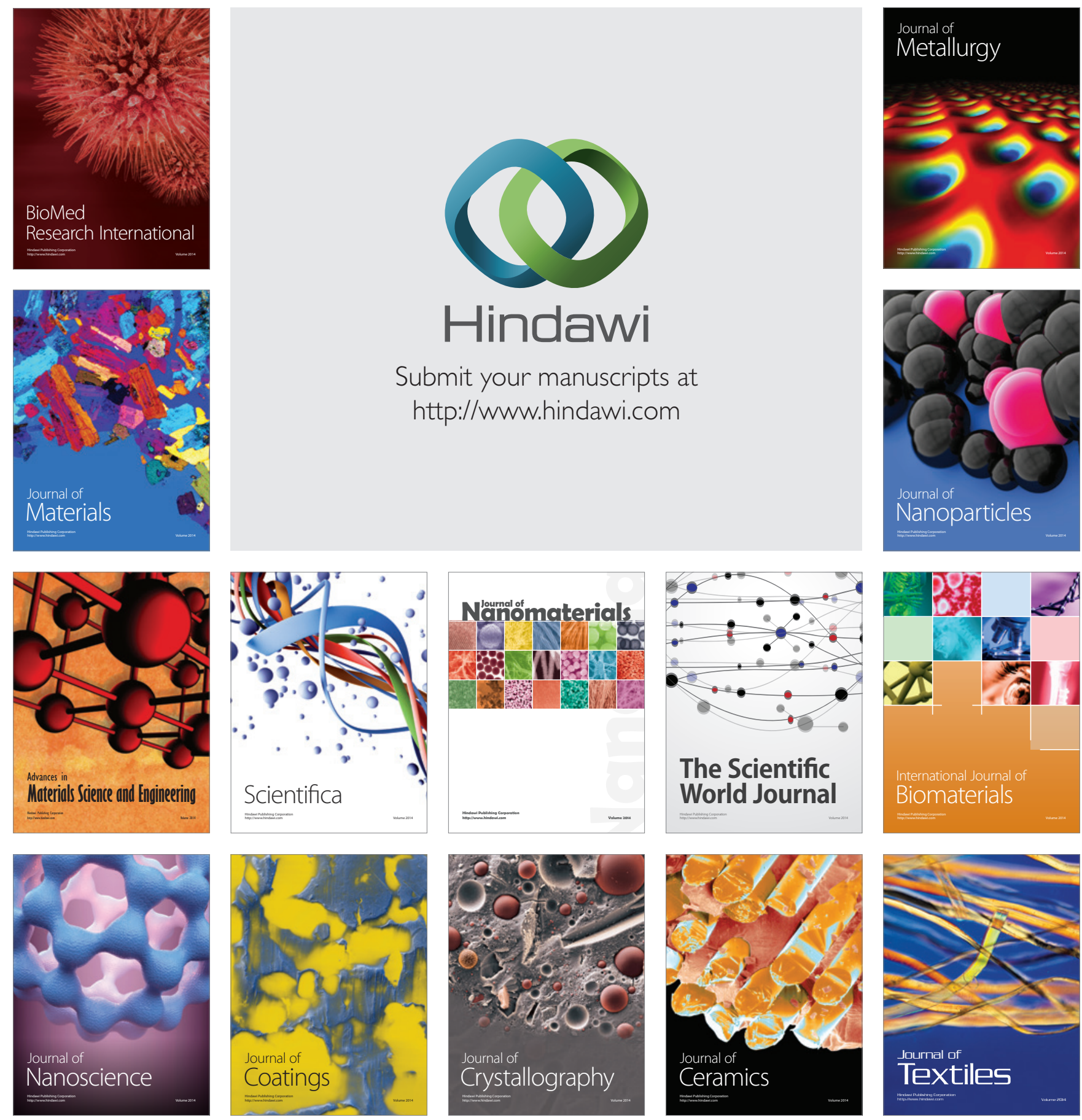